\title{
Characteristics of Jackfruit Straw's Edible Film Enriching by Gingers Red (Zingiber officinale, Rosc.)
}

\author{
Neswati, Wenny Surya Murtius, Andini Prastica \\ Department of Technology of Agricultural Product, Faculty of Agricultural Technology, Andalas University, Padang, Indonesia \\ E-mail: neswati.aulia@gmail.com
}

\begin{abstract}
This research was aimed to determine the effect of the addition red ginger's(Zingiber officinale, Rosc.) concentrate toward psycochemical, and sensory evaluation of edible film from jackfruit straw's. Using design is Completely Randomized Designed (CRD) consist of 5 treatments (The addition of red ginger's concentrate $2 \%, 4 \%, 6 \%, 8 \%$, and $10 \%$ ) and 3 replications. Data was analysed statiscally with ANOVA and were continued with Duncan's New Multiple Range Test (DNMRT) at 5\% significance level. This research determined the addition of red ginger's concentrate significantly affected toward aw, thickness and water vapor transmission rate, but not significantly affected toward water content. The best edible film were determined based on sensory evaluation on packaging of galamai, showed Treatment $B$ as the best product with panelist prefferences at color $(3,70)$, flavor $(3,80)$, taste $(3,75)$, and texture $(3,50)$. For physical and chemical characteristic water content $12,6711 \%$, aw 0,4263 , thickness 0,0929 mm, water vapor transmission rate $0,0635 \mathrm{~g} / \mathrm{m} 2$.jam.
\end{abstract}

Keywords — Edible film; Jackfruit straw's; gingers red

\section{INTRODUCTION}

Edible films is produced from edible biopolymers and food-grade [1]. The use of edible films as primary packaging can potentially replace conventional packaging materials, partially or totally, which can reduce the overall utilization of synthetic materials [2],[3].

Film-forming biopolymers can be proteins, polysaccharides (carbohydrates and gums), lipids, or a mixture of these [4]. The raw material of the potential of edible film developed is jackfruit straw.

Jackfruit straw is a waste jackfruit having taken flesh and not including the skin and seeds. According [5], 40-50\% of waste is jackfruit straw. It contain carbohydrates that consists of glucose, fructose, sucrose, starch, pectin and also contain cellulose which is quite high. Renewable sources for biopolymers include polysaccharides such as pectin, a naturally occurring, hydrophilic polysaccharide found in plant cell walls which has good film forming properties [6].

Using of red ginger can improve the functional properties of jackfruit straw's edible film. Red Ginger contains essential oils (especially gingerol) which function as antimicrobial. Besides antimicrobial properties, EO- or OCcontaining edible films may have improved barrier [7], antioxidative, sensory [8],[9], mechanical properties [10].
Applications of edible films containing essential oils (EOs) of red ginger may be affect sensory of galamai. Galamai is a traditional food of West Sumatra (derived from Payakumbuh) which is made from glutinous rice flour and coconut milk cooked with sugar dissolved in it. Galamai are packed with edible films containing Essential oil of red ginger will affect sensory properties. This study aims to investigate the characteristics of edible films containing red ginger essential oil and its influence on the sensory properties galamai.

\section{MATERIALS AND METHODS}

\section{A. Materials}

The main raw material used in this study is jackfruit straw and red ginger that has been aged 7-8 months, distilled water, glycerol and $\mathrm{CMC}$, and galamai for packaging applications the use of edible film produced and other chemicals for analysis.

\section{B. Extraction of Red Ginger}

Taken ginger rhizome is the part that is still fresh. Cleaned and peeled ginger and wash with distilled water. Red ginger crushed using a juicer and red ginger rhizome extract obtained. 


\section{Making of Edible Film}

Jackfruit straw has destroyed and taken the filtrate 100 $\mathrm{ml}$, then added with $5 \%$ glycerol plasticizer and $(\mathrm{w} / \mathrm{v})$, stirring evenly, CMC $1 \%$ which has been previously dissolved, while continuing to be heated. The mixture is stirred with a magnetic stirrer and heated to $70{ }^{\circ} \mathrm{C}$ with a hotplate. Allow approximately up to a temperature of $45^{\circ} \mathrm{C}$ and then add red ginger rhizome extract $(2 \%, 4 \%, 6 \%, 8 \%$ and $10 \%)$. Printing is done by pouring a solution of the film into the glass plate with a size of $20 \mathrm{~cm} \times 20 \mathrm{~cm} \times 2 \mathrm{~mm}$ [11].

The next stage is drying by using an oven at $60^{\circ} \mathrm{C}$ for 24 hours. Let stand for 10 minutes at room temperature, the film then removed from the glass plate.

\section{Application of Edible Film on the Galamai}

The film is formed on each treatment is cut to size and made packaging to galamai. Galamai are packed with plastic packaging used as controls. Then galamai already packed with edible films containing red ginger extract and do sensory test.

\section{E. Water Content}

Samples 1-2 g dried in an oven at $100^{\circ} \mathrm{C}$ for 3-5 hours, depending on the material [12]. After the sample is inserted in a desiccator and weigh. The water content was calculated by the formula:

$$
\text { Water content }=\frac{a-b}{a} \times 100 \%
$$

$\mathrm{a}=$ Initial weight of the sample;

$\mathrm{b}=$ Weight after drying of the sample

\section{F. Water Activity $\left(\mathrm{a}_{\mathrm{w}}\right)$}

Measurement of water activity carried out by using $a_{w}$ meter. Edible films are cut into small pieces weighing 1-3 grams and placed in the measuring cup $a_{w}$. The recording was made of the value of $a_{w}$.

\section{G. Thickness}

The resulting of film thickness was measured using a micrometer with an accuracy of $0.001 \mathrm{~mm}$ [13]. Measurements were taken at five different places. The measurement results were averaged as a result of the film thickness and expressed in $\mathrm{mm}$.

\section{H. Water Vapor Transmission Rate}

Edible films cut $5 \mathrm{~cm}$ in diameter and placed between two containers (glass beverage) [14] .The first container filled water and the second container filled which known its weight. Then allowed to stand for 1 hour and water vapor transmission is calculated by the formula:

$$
\text { Water Vapor Transmission Rate }=\frac{W}{A}
$$

$\mathrm{W}=$ weight change;

$A=$ area of the film $\left(\mathrm{m}^{2}\right)$

\section{Sensory Evaluation}

The sensory quality of galamai sample was evaluated by a 20 member panel from the laboratory [15]. The galamai samples of the different treatments were individually presented in covered small porcelain dishes to each panelist. The samples were blind-coded with 3-digit random numbers. Panel scored for sensory characteristics, such as color, odor, taste and texture using a five point hedonic scale $(1=$ dislike $(\mathrm{DL}), 2$ = less like $(\mathrm{LL}), 3=\operatorname{regular}(\mathrm{R}), 4=$ like $(\mathrm{L}), 5=$ very like (VL).

\section{J. Statistical Analysis}

The design used in this study is completely randomized design with five treatments and three replications.If the result shows a diffrence due to the treatment, then Followed by test Dunncan's New Multiple Range Test (DNMRT) at the $5 \%$ significance level.

\section{RESULT AND DISCUSSION}

\section{A. Water Content}

The water content is very influential in determining the shelf life of food products. Results of analysis of variance showed that the addition of red ginger extract is no significant on the moisture content of edible film of jackfruit straw. Moisture content of edible film can be seen in Figure 1.

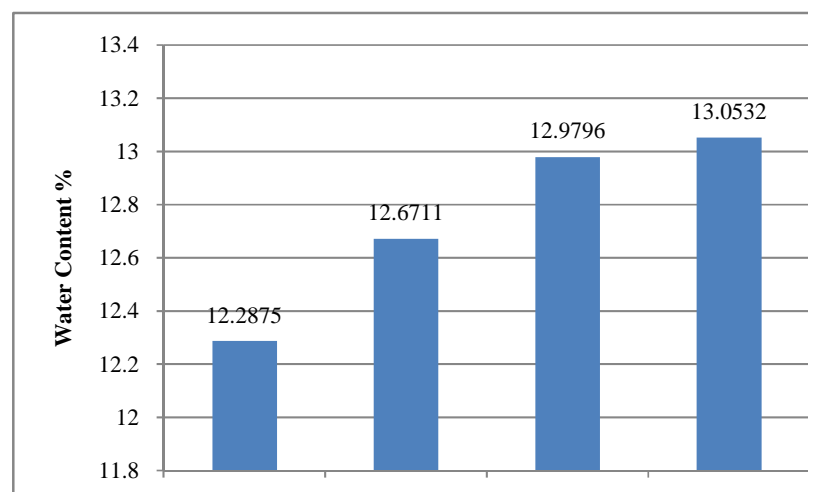

Fig 1. Water content of edible film of jackfruit straw with addition red ginger extract (Zingiber officinale, Rosc.)

Water content can be distinguished on the free water and bound water contained in the material woven network. The drying process begins with the evaporation of free water that requires less energy because the process occurs more quickly and easily. If all the free water is drained, the moisture content of the material reaches 12 to $25 \%$ [16]. Subsequent drying process is the evaporation of water bound which require greater energy. If the bound water is removed entirely, then the moisture content of the material will range from 3 to $7 \%$ and optimum stability will be achieved [17].

\section{B. Water Activity (aw)}

Water activity $\left(\mathrm{a}_{\mathrm{w}}\right)$ was very influential in determining the shelf life of food products. Results of analysis of variance showed that the addition of red ginger extract significantly different with a water activity $\left(\mathrm{a}_{\mathrm{w}}\right)$ jackfruit straw's edible film. Results DNMRT test (Duncan's New Multiple Range Test) can be seen in Figure 2.

Increasing the concentration of red ginger extract showed significant difference at 5\% level. This is caused by the increasing number of additions of red ginger extract, then the free water content in the sample increased so that the value 
of $a_{w}$ is also increasing. [18] stated moisture content and $a_{w}$ relationship shown by the tendency that the higher the water content the higher the value of aw, where water levels are expressed in percent $(\%)$ in the 0-100 scale, while the $a_{w}$ value expressed in decimal number in the range 0-1.0 scale.

Increasing the concentration of red ginger extract showed significant difference at $5 \%$ level. This is caused by the increasing number of additions of red ginger extract, then the free water content in the sample increased so that the value of $a_{w}$ is also increasing. [18] stated moisture content and $a_{w}$ relationship shown by the tendency that the higher the water content the higher the value of aw, where water levels are expressed in percent $(\%)$ in the $0-100$ scale, while the $a_{w}$ value expressed in decimal number in the range 0-1.0 scale.

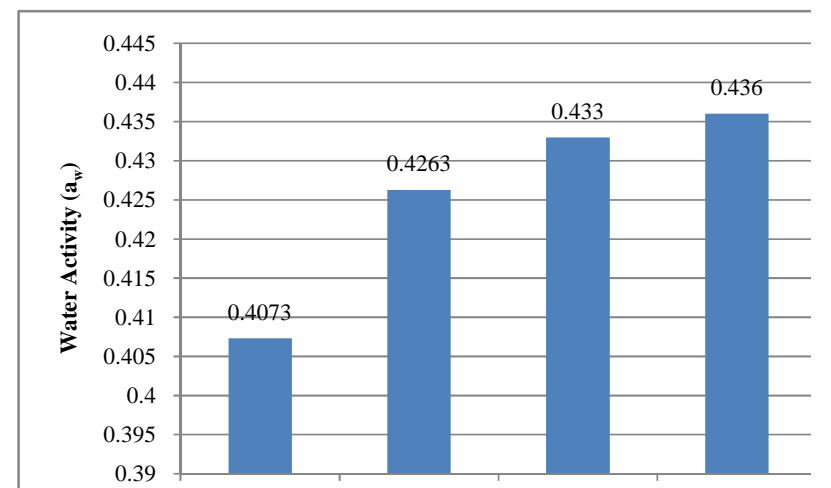

Fig 2. Water activity of edible film of jackfruit straw with addition red ginger extract (Zingiber officinale, Rosc.)

Water activity $\left(\mathrm{a}_{\mathrm{w}}\right)$ is the amount of water available in groceries that determine the processes of decay of food. Test the water activity $\left(\mathrm{a}_{\mathrm{w}}\right)$ is intended to calculate the amount of free water in the sample edible film. The term used to describe the water activity of water that is not bound or free in a system that can support biological and chemical reactions. Various microorganisms have a minimum $\mathrm{a}_{\mathrm{w}}$ for growth, such as bacteria $\mathrm{a}_{\mathrm{w}} 0.90,0.80-0.90 \mathrm{a}_{\mathrm{w}}$ of yeasts, and molds $\mathrm{a}_{\mathrm{w}}$ of $0.60-0.70$ [19].

According to [19] that the value $\left(a_{w}\right)$ from 0.20 to 0.50 is the range of values $\left(a_{w}\right)$ which microorganisms can not grow in fertile. The value of water activity $\left(a_{w}\right)$ was measured to determine the possibility of product contamination by microbial growth. Based on the value obtained, it can be concluded that the edible film safe from microbial growth.

Requirements for the $\mathrm{a}_{\mathrm{w}}$ value of edible film yet, but when compared with studies [20] states that the tapioca starch's edible films have $a_{w}$ value of 0.456 . So also with the research [21] $a_{w}$ value of edible film surimi eel with tapioca is $0: 27$ to $0: 41$. This result is not much different from the $a_{w}$ value $0.4073-0.4373$.

\section{Thickness}

Thickness is an important parameter that affects the use of films on the products. The thickness of the edible film to be adapted to the product [22]. Results of analysis of variance showed that the addition of red ginger extract significantly different with edible film thickness jackfruit straw. Results DNMRT test (Duncan's New Multiple Range Test) can be seen in Figure 3.
Based on Figure 3 noted that edible film thickness ranged between $0.0929-0.1219 \mathrm{~mm}$. The value of the film thickness meets the standards of JIS 1975 , ie a maximum of $0.25 \mathrm{~mm}$. Increasing the concentration of red ginger extract showed significant difference at 5\% level. The more the addition of red ginger extract on edible film, the thickness will also be higher. This is because red ginger juice still contain dissolved solids, such as starch. According to [23], red ginger has a starch content of $52.9 \%$. The more the ginger juice is added, the more amylose in the film matrix. [11] states that the composition of the molecular structure of amylose is straight and unbranched with $1.4 \alpha$ - glycosidic bond, thus the more there is accumulation of amylose and the resulting film is getting tight and thick. [24] explained that the amylose molecules are most responsible for the formation of edible film.

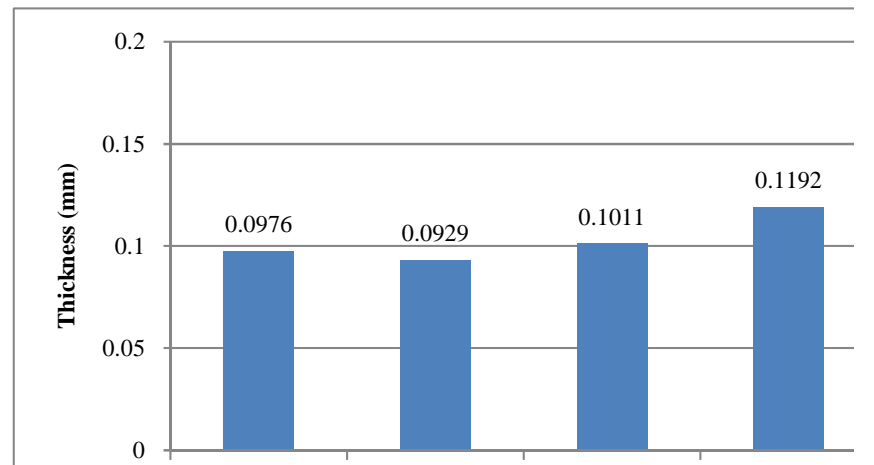

Fig. 3. Thickness Of Edible Film Of Jackfruit Straw With Addition Red Ginger Extract (Zingiber Officinale, Rosc.)

Amaliya et al [25] also stated that the higher the concentration of white turmeric cause edible film thickness will increase. Allegedly the addition of white turmeric filtrate in large numbers would increase the total amount of solids so that the film thickness increases. The film thickness obtained ranges $0.080-0.240 \mathrm{~mm}$. In a study of [26], thickness derived from corn starch edible films incorporated with the juice of chinese ginger is 0.061-0.170 mm. This result is not much different when compared to the film thickness obtained by the $0.092-0.121 \mathrm{~mm}$.

\section{Water Vapor Transmission Rate}

One of the main functions of edible film is to hold water vapor migration, the permeability to water vapor should be as low as possible [14]. Results of analysis of variance showed that the addition of red ginger extract significantly different with the water vapor transmission rate of jackfruit straw's edible film. Results DNMRT test (Duncan's New Multiple Range Test) can be seen in Figure 4.

Increasing the concentration of red ginger extract showed significant difference at 5\% level. The Addition of red ginger extract is higher cause the water vapor transmission rate is smaller. According to [23], red ginger content essential oils $3.9 \%$. Components of essential oils of red ginger are hydrophobic substances (e.g. gingerol) which can inhibit the penetration of water from the environment to galamai. [27] adding hydrophobic substances (e.g., cinnamaldehyde) is expected to improve the moisture barrier properties of a film. 


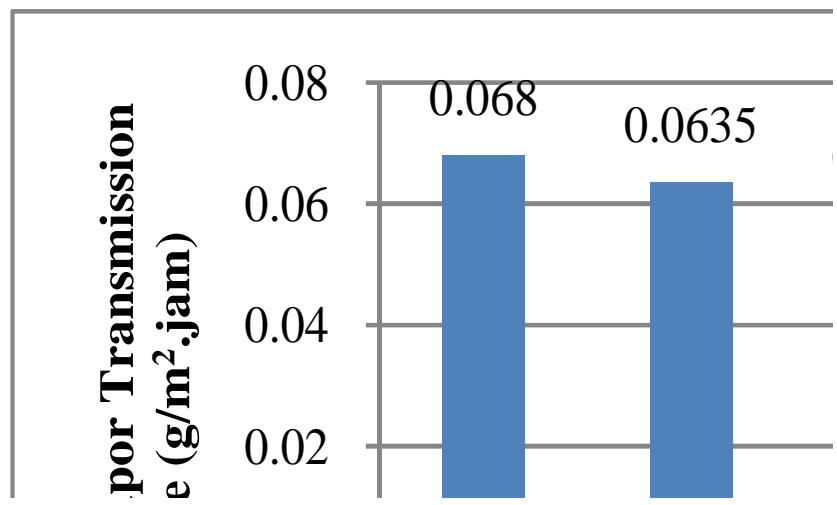

Fig. 4. Water vapour transmission rate of edible film of Jackfruit Straw With Addition Red Ginger Extract (Zingiber officinale, Rosc.)

The water vapor transmission rate is also influenced by the film thickness, the thicker films produced then diminishing its ability to absorb moisture. This is corroborated by a study [26], the high concentration of corn starch will increase the amount of film-forming polymer, while the increase in the juice of chinese ginger also increase the total solids, so it can form a thick edible film. Increasing the amount of polymer, will minimize the cavity formed in the gel. The thicker and dense matrix formed films can reduce the water vapor transmission rate because it is difficult to penetrate the water vapor.

Siswanti [28] also mentions in his research, that the increasing concentration of glucomannan, it can lower the water vapor transmission rate. This is due to the increased molecules of solution cause the structure of the film is more strong and compact, so that the film can hold water vapor transmission rate.

Krochta [29] states that the value of the water vapor transmission rate can be used to determine the shelf life of the product. If the water vapor transmission rate can be retained, then the product shelf life can be extended. The water vapor migration is smaller which is the better properties of edible film in maintaining the shelf life of products.

\section{E. Sensory Evaluation}

Sensory evaluation was conducted to determine panelists assessment of the product. Methode of the sensory evaluation is hedonic test for color, aroma, flavor, and texture resulting from each treatment.

1) Color: Color is a very important component to determine the quality of food. Determining the quality of a food is generally dependent on the color, because color appears first [17].

TABLE I

Average Of Color Of Galamai Which Has BeEn Wrapped Edible FILM OF JACKFRUIT STRAW WITH ADDITION RED GINGER EXTRACT (ZINGIBER OFFICINALE, ROSC.)

\begin{tabular}{|c|c|}
\hline Treatments & Color \\
\hline Galamai + Extract of red ginger $2 \%$ & 3.75 \\
\hline Galamai + Extract of red ginger $4 \%$ & 3.70 \\
\hline Galamai + Extract of red ginger $6 \%$ & 3.50 \\
\hline Galamai + Extract of red ginger $8 \%$ & 3.55 \\
\hline Galamai + Extract of red ginger $10 \%$ & 3.45 \\
\hline
\end{tabular}

$1=$ dislike $(\mathrm{DL}), 2$ = less like $(\mathrm{LL}), 3=\operatorname{regular}(\mathrm{R}), 4=$ like $(\mathrm{L}), 5=$ very like (VL)).
Table I showed that the most preferred color is galamai + extract of red ginger $2 \%$. Color of galamai which wrapped edible film of jackfruit straw with the addition of red ginger extract is visually not affect the galamai original color is dark brown. This is because the color of galamai be more dominant than the color of its edible film ( brownish yellow), so the color of the edible film covered by galamai color (dark brown). This causes the panelists difficult to compare the differences in color on galamai wrapped edible film for each treatment.

2) Aroma: According to [17], each fruit has a distinctive aroma and additions to a particular material in a processing can affect the taste and aroma.

\section{TABLE II}

Average Of Aroma Of Galamai Which Has Been Wrapped Edible FILM OF JACKFRUIT STRAW WITH ADDITION RED GINGER EXTRACT (ZINGIBER OFFICINALE, ROSC.)

\begin{tabular}{|c|c|}
\hline Treatments & Aroma \\
\hline Galamai + Extract of red ginger 2\% & 3.50 \\
\hline Galamai + Extract of red ginger 4\% & 3.80 \\
\hline Galamai + Extract of red ginger 6\% & 3.50 \\
\hline Galamai + Extract of red ginger 8\% & 3.40 \\
\hline Galamai + Extract of red ginger 10\% & 3.40 \\
\hline
\end{tabular}

$1=\operatorname{dislike}(\mathrm{DL}), 2=$ less like $(\mathrm{LL}), 3=\operatorname{regular}(\mathrm{R}), 4=$ like $(\mathrm{L}), 5=$ very like (VL)).

Table II showed that the most preferred aroma is galamai + extract of red ginger $4 \%$ because ginger aroma that is not overly dominant. According to [30], red ginger has the smallest size and highest level of spiciness than the other two types of ginger. The aroma of the red ginger is highly dependent on essensial oil content (1-3\%).

3) Taste: According to [17], the taste of food can affect customer preference with food. Taste is an important factor for determining the admissibility of a food or food ingredient.

TABLE III

Average Of Taste Of Galamai Which Has BeEn Wrapped Edible FILM OF JACKFRUIT STRAW WITH ADDITION RED GINGER EXTRACT (ZINGIBER OFFICINALE, ROSC.)

\begin{tabular}{|c|c|}
\hline Treatments & Taste \\
\hline Galamai + Extract of red ginger 2\% & 3.65 \\
\hline Galamai + Extract of red ginger 4\% & 3.75 \\
\hline Galamai + Extract of red ginger 6\% & 3.35 \\
\hline Galamai + Extract of red ginger 8\% & 3.40 \\
\hline Galamai + Extract of red ginger 10\% & 3.45 \\
\hline
\end{tabular}

$1=\operatorname{dislike}(\mathrm{DL}), 2$ = less like $(\mathrm{LL}), 3=\operatorname{regular}(\mathrm{R}), 4=$ like $(\mathrm{L}), 5=$ very like (VL)).

Table III showed that The most preferred flavor is galamai + extract of red ginger $4 \%$. Taste in galamai wrapped edible film of jackfruit straw with the addition of extract of red ginger produced which is a blend of sweet and spicy taste. The taste of spicy derived from extract of red ginger.

4) Texture: Texture is a sensation of pressure that can be felt by mouth (at the time bitten, chewed, and swallowed) or using palpation with the finger [15]. Table IV showed that the most texture preferred is galamai+ extract of red ginger $8 \%$. 
TABLE IV

Average Of TeXture Of Galamai Which Has BeEn Wrapped Edible FILM OF JACKFRUIT STRAW WITH ADDITION RED GINGER EXTRACT (ZINGIBER OFFICINALE, RosC.)

\begin{tabular}{|c|c|}
\hline Treatments & Texture \\
\hline Galamai + Extract of red ginger 2\% & 3.40 \\
\hline Galamai + Extract of red ginger 4\% & 3.50 \\
\hline Galamai + Extract of red ginger 6\% & 3.45 \\
\hline Galamai + Extract of red ginger 8\% & 3.70 \\
\hline Galamai + Extract of red ginger 10\% & 3.60 \\
\hline
\end{tabular}

$1=\operatorname{dislike}(\mathrm{DL}), 2$ = less like $(\mathrm{LL}), 3=\operatorname{regular}(\mathrm{R}), 4$ = like $(\mathrm{L}), 5=$ very like (VL)).

\section{IV.CONCLUSIONS}

The addition of extract of red ginger effect on water activity $\left(a_{w}\right)$, thickness, and water vapor transmission rate of edible film of jackfruit straw. The best treatment is extract of red ginger $4 \%$ with characteristics of color 3.70 , aroma 3.80, flavor 3.50 and texture 3.75 , water content $12.6711 \%$, $\mathrm{a}_{\mathrm{w}}$ 0.4263, thickness $0.0929 \mathrm{~mm}$, and water vapor transmission rate $0.0635 \mathrm{~g} / \mathrm{m}^{2}$.jam.

\section{ACKNOWLEDGMENT}

The author greatfully acknowledges the financial support from DIPA Faculty of Agricultural Technology, Andalas University.

\section{REFERENCES}

[1] Han, J.H. 2014. Edible Films and Coatings: A Review. Elsevier Ltd. $\mathrm{P}: 214-24$.

[2] Krochta, J.M., C. De Mulder-Johnston. 1997. Edible and biodegradable polymer films: challenges and opportunities. Food. Technol. 51 (2), 61 74.

[3] Petersen, K., P.V.Nielsen,,G. Bertelsen. 1999. Potential of biobased materials for food packaging. Trends Food Sci. Technol. 10, 52 68.

[4] Gennadios, A., Hanna, M.A., Kurth, L.B., 1997. Application of edible coatings on meats,poultry and seafoods: a review. Lebensm. Wiss. Technol. 30 (4), 337350

[5] Garusti. 2014. Analisis Penerimaan Konsumen untuk Edible Film Berbahan Tepung Dami Nangka sebagai Bahan Kemasan Serbuk Sereal. Uniersitas Gajah Mada. Yogyakarta.

[6] Espitia, P. J. P., W.-X. Du, R. J. Avena-Bustillos, N. F. F. Soares, \& T. H . McHug,. (2014). Edible films from pectin: physicalmechanical and antimicrobial properties e a review. Food Hydrocolloids, 35, 287e296.

[7] Mancini, F., \& McHugh, T. H. (2000). Fruit-alginate interactions in novel restructured products. Nahrung, 44, 152e157.

[8] Bakkali, F.,S. Averbeck, D. Averbeck, \& M. Idaomar. (2008). Biological effects of essential oils e A review. Food and Chemical Toxicology, 46, 446e 475 .

[9] De Rovira, D. (2008). Dictionary of flavors. (2nd ed.). WileyBlackwell. Iowa, USA.

[10] Du,W.-X., C.W.Olsen, R. J. Avena-Bustillos, T. H. McHugh, C. E. Levin, \& M. Friedman.(2008). Storage stability and antimicrobial activity against Escherichia coli O157: $\mathrm{H} 7$ of carvacrol in edible apple films prepared by two different casting methods. Journal of Agricultural and Food Chemistry, 56, $3082 \mathrm{e} 3088$.
[11] Santoso, B., F.Pratama, B.Hamzah, dan R. Pambayun. 2011 Pengembangan Edible Film dengan Menggunakan Pati Ganyong Termodifikasi Ikatan Silang. Jurnal Teknologi dan Industri, vol.XXI.

[12] Sudarmadji, S., B. Haryono, dan Suhardi. 1997. Prosedur Analisa Bahan Makanan dan Pertanian. Liberty, Yogyakarta. 172 hal.

[13] McHugh, T.H., 1993. Hydrophilic Edible films : Modified Procedure for Water Vapor Permeability and Eksplanation of Thickness Effects. Journal of Food Science Vol. 58, No.4.

[14] Gontard,N., S. Guilbert.,J.L. Cuq. 1993. Water and Glyserol as plasticizer Affect Mechanical and Water Barrier Properties at an Edible Wheat Gluten Film. J. Food Science. 58 (1): 206-211

[15] Soekarto, S.T. 1985. Penilaian Organoleptik. Pusat Pengembangan Teknologi Pangan IPB. Bogor.

[16] Taib, G., G. Said dan S. Wiraatmadja. 1988. Operasi Pengeringan Pada Pengolahan Hasil Pertanian. PT Mediatama Sarana Perkasa. Jakarta.

[17] Winarno FG. 2004. Kimia Pangan dan Gizi. Jakarta: Gramedia.

[18] Legowo, A.M., dan Nurwantoro. 2004. Analisis Pangan. Fakultas Peternakan. Universitas Diponegoro.Semarang

[19] Buckle, K.A., R.A.Edwards, G.H.Fleet and m.Wootton. 1987. Ilmu Pangan. Terjemahan H.Purnomo dan Adiono. Ui-Press. Jakarta.

[20] Harris, H. 2001. Kemungkinan Penggunaan Edible Film dari Pati Tapioka untuk Pengemas Lempuk. Jurnal Ilmu-Ilmu Pertanian Indonesia. Volume 3, No.2, 2001. Hal 99-106. Bengkulu: Fakultas Pertanian Universitas Bengkulu.

[21] Santoso, B., Herpandi., V. Ariani, dan R. Pambayun. 2013. Karakteristik Film pelapis Pangan dari Surimi Belut Sawah dan Tapioka. Jurnal Teknologi dan Industri Pangan, Vol. 24 No. 1

[22] Kusumasmarawati, A.D., 2007. Pembuatan Pati Garut Butirat dan Aplikasinya dalam Pembuatan Edible Film. Tesis. Program Pascasarjana. UGM. Yogyakarta

[23] Hernani dan E. Hayani. 2001. Identification of Chemichal Components on Red Ginger (Zingiber officinale var. Rubrum) by GC-MS. Proc. International Seminar on Natural Products Chemistry and Utilization of Natural Resources. UI-Unesco, Jakarta : 501-505

[24] Brandelero, R.P.H, F. Yamashita, and M.V.E. Grossmann. 2010. The Affect of Surfactant Tween 80 on The Hydrophilicity Water Vapor Permeation and The Mechanical Properties of Cassava Starch and Poly (Butylenes Adipate-co-terphtalate) (PBAT) Blend Films.Carbohyd Polym 82:1102-1109.

[25] Amaliya, R.R., dan Putri W.D.R. 2014. Karakterisasi Edible Film dari Pati Jagung dengan Penambahan Filtrat Kunyit Putih sebagai Antibakteri. [Jurnal] Pangan dan Agroindustri Vol. 2 No. 3 p.43-53, Juli 2014.

[26] Kusumawati, D.H., dan W.D.R . Putri. . 2013. Karakteristik Fisik dan Kimia Edible Film Pati Jagung yang diinkorporasi dengan Perasan Temu Hitam. Jurnal Pangan dan Agroindustri Vol 1. No.1 p. 99-100, Oktober 2013.

[27] Caio G. Otoni, Márcia R. de Moura, Fauze A. Aouada, Geany P. Camilloto,Renato S. Cruz, Marcos V. Lorevice, Nilda de F.F. Soares, Luiz H.C. Mattoso. 2014. Antimicrobial and physical-mechanical properties of pectin/papaya puree/cinnamaldehyde nanoemulsion edible composite films. C.G. Otoni et al. / Food Hydrocolloids 41 (2014) 188-194

[28] Siswanti. 2008. Karakterisasi Edible film Dari Tepung Komposit Glukomanan Umbi Iles-Iles (Amorphopallus Muelleri Blume) dan Tepung Maizena. Skripsi. UNS. Surakarta.

[29] Krochta, J.M, E.A. Baldwin and M. Nisperos-Carriedo. 1994. Edible Coating and Film to Improve Food Quality. Technomic Publishing Co. Inc. Landcaster. Basel.

[30] Prayitno, D. 2002. Tanaman Obat dan Manfaatnya. IP2TP. Yogyakarta 